\title{
First report of Cucurbit aphid-borne yellows virus in Turkey
}

\author{
N. Yardımc $\iota^{\mathrm{A}, \mathrm{B}}$ and H. Özgönen ${ }^{\mathrm{A}}$ \\ A Süleyman Demirel University Faculty of Agriculture, Plant Protection Department, Çünür, Isparta 32260, Turkey. \\ ${ }^{B}$ Corresponding author. Email: nejyard@ziraat.sdu.edu.tr
}

\begin{abstract}
Cucurbit aphid-borne yellows virus was detected for the first time in Turkey. A range of cucurbit species grown in the Isparta region, south-west Turkey, tested positive for the virus as assessed by the double antibody sandwich enzyme-linked immunosorbent assay.
\end{abstract}

In Turkey, cucurbit crops are seriously affected by many viruses that are non-persistently transmitted by aphids, among which Cucumber mosaic virus (CMV, genus Cucumovirus, family Bromoviridae), Watermelon mosaic virus 2 (WMV-2, genus Potyvirus, family Potyviridae) and Zucchini yellow mosaic virus (ZYMV, genus Potyvirus, family Potyviridae) are most prevalent in the region (Yardimct et al. 2000; Ozaslan et al. 2006). During summers of 1998 and 2000, virus-like symptoms were noticed on many cucurbits species (cucumbers, squashes, watermelons, muskmelons) grown in the south-west region of Turkey. The symptoms were widespread and included initial chlorotic lesions followed by yellowing of whole leaves and thickening of older leaves, suggesting the presence of Cucurbit aphid-borne yellows virus (CABYV; genus Polerovirus, family Luteoviridae) (Lecoq et al. 1992; Lemaire et al. 1993; Dogimont et al. 1996). The symptoms were associated with severe losses on cucurbit plants in the south-west region.

Twenty commercial and home gardens were visually examined and in total 200 samples were collected during 1998-2000. Leaf and fruit samples showing typical symptoms were collected from six cucurbit species including pumpkin (Cucurbita maxima L., 30 plants sampled), muskmelon (Cucumis melo L. 'Hasanbey', 14 plants sampled), cucumber snake melon (C. melo var. Flexious, 20 plants sampled), cucumber (C. sativus L., 56 plants sampled), squash (Cucurbita pepo L., 64 plants sampled) and watermelon (Citrullus lanatus 'Paladin', 16 plants sampled). Several viruses were detected by double antibody sandwich enzyme-linked immunosorbent assay (DAS-ELISA), including CABYV using an antiserum provided by Dr Lecoq (INRA, Bordeaux, France). Samples with DASELISA values at least twice the negative control were considered as positive (Stellmach 1985). CABYV was detected for the first time in cucurbit-growing areas of the Isparta region of Turkey with 94 of the 200 samples positive for CABYV. This survey detected the presence of CABYV at incidences between 30 and $100 \%$ in the different cucurbits tested (C. maxima, C. melo 'Hasanbey', C. melo var. Flexious, C. sativus, C. pepo and C. lanatus 'Paladin'), which were grown in fields within the Isparta region. Multiple infections by CMV, WMV-2, ZYMV and CABYV were also detected (data not shown).

CABYV is transmitted only by aphids (e.g. Aphis gossypii and Myzus persicae) and in a persistent manner (Lecoq et al. 1992; Dogimont et al. 1996). The occurrence and wide distribution of CABYV in cucurbit plants was most likely related to the large abundance of aphids in this region. Fourteen aphid species belonging to eight genera and three families of the superfamily Aphidoidea were present in the Isparta region (Aslan and Karaca 2005). CABYV is widespread throughout the Mediterranean basin where it has been shown to significantly reduce the yields of cucurbits (Lecoq et al. 1994). However, a previous survey of viruses infecting cucurbits grown in Turkey did not detect the occurrence of CABYV (Ozaslan et al. 2006). Therefore, to our knowledge, this is the first record of the occurrence of CABYV in Turkey.

\section{References}

Aslan B, Karaca I (2005) Fruit tree aphids and their enemies in Isparta region, Turkey. Journal of Pest Science 78, 227-229. doi: 10.1007/s10340-0050097-2

Dogimont C, Slama S, Martin J, Lecoq H, Falk BW (1996) Sources of resistance to cucurbit aphid-borne yellows luteovirus in a melon germplasm collection. Plant Disease 80, 1379-1382.

Lecoq H, Bourdin D, Wipfscheibe LC, Bon M, Lot H, Lemaire O, Herrbach E (1992) A new yellowing disease of cucurbits caused by a luteovirus, cucurbit aphid-borne yellows virus. Plant Pathology 41, 749-761.

Lecoq H, Gilbert-Albertini F, Wipfscheibel C, Pitrat M, Bourdin D, Belkhala H, Katis N, Y1lmaz M (1994) Occurrence of a new yellowing disease of cucurbits in the Mediterranean basin caused by a luteovirus, cucurbit aphid-borne yellows virus and prospects for control. In 'The 9th Congress of the Mediterranean Phytopathological Union. September 18-24, 1994, Kusadasi-Aydin, Turkey’. pp. 461-463.

Lemaire OJ, Gubler WD, Valencia J, Lecoq H, Falk BW (1993) First report of Cucurbit Aphid-Borne Yellows Luteovirus in the United States. Plant Disease 77, 1169.

Ozaslan M, Aytekin T, Bas B, Kilic H, Afacan ID, Dag DS (2006) Virus Diseases of Cucurbits in Gaziantep, Turkey. The Plant Pathology Journal 5, 24-27.

Stellmach G (1985) ELISA testing of Grapevine rootings reared from nepovirus-infected mother plants forced to rapid growth. Phytopathologia Mediterranea 24, 123-124.

Yardımcı N, Özgönen H, Arıcı E (2000) Studies on the identification of virus diseases on Cucurbitaceae plants in Isparta. In 'The 3rd vegetable symposium. September 11-13 Isparta, Turkey’. pp. 208-212.

Manuscript received 15 December 2006, accepted 28 March 2007 